\title{
PEMBENTUKAN POLIEMBRIONI PADA BIJI BUAH JERUK PERAS (Citrus sinensis L.)
}

\section{THE POLYEMBRIONIC FORMATION ON SQUEEZED ORANGE FRUIT SEEDS (Citrus sinensis L.)}

\author{
Aditya Wahyudhi* \\ Program Studi Pemuliaan Tanaman, Fakultas Pertanian, Universitas Gadjah Mada \\ Jl. Flora No. 1, Bulaksumur, Yogyakarta
}

Korespondensi : adityawahyudhi2@gmail.com

\begin{abstract}
ABSTRAK
Poliembrioni merupakan pembentukan lebih dari satu embrio yang terjadi pada biji yang dikecambahkan. Terjadinya poliembrioni akibat zigot yang terpecah, perkembangan satu atau lebih sinergit, dan terdapat satu atau lebih kantung embrio per inti sel, dan variasi bentuk adventif dari embrio. Tujuan penelitian untuk mengkaji pembentukan benih poliembrioni pada buah jeruk peras dan mempelajari pertumbuhan bibit dari benih poliembrioni. Berdasarkan pengamatan terhadap beberapa buah jeruk peras didapat bahwa rerata persentase pembentukan benih poliembrioni pada setiap buah jeruk peras yaitu 47,92\%. Adapun pertumbuhan bibit jeruk asal benih poliembrioni saat berumur 4 minggu yaitu tinggi tanaman rata-rata sebesar $3,075 \mathrm{~cm}$, diameter biji $0,111 \mathrm{~cm}$, jumlah daun 2 helai, luas daun $2,21 \mathrm{~cm}^{2}$, berat kering bibit $0,34 \mathrm{~g}$, dan vigor hipotetis sebesar 7,76. Bibit jeruk yang tumbuh dari embriozigotik umumnya memiliki tampilan yang berbeda dari induknya karena gen yang berasa dari dua tetua. Namun bibit yang tumbuh dari embrio nuselar memiliki tampilan yang sama dengan induk betina akibat diferensiasi sel somatik.
\end{abstract}

Kata kunci: biji, embrio, jeruk, vigor hipotetik

\begin{abstract}
Polyembryony is the formation of more than one embryo that occurs in germinated seeds. The occurrence of polyembryony due to the zygote is split, the development of one or more synergies, and there are one or more embryonic sacs per cell nucleus, and adventitious form variations of the embryo. The aim of this research was to study the formation of polyembryonic seeds in squeezed oranges and to study the growth of seeds from polyembryonic seeds. Based on observations of several squeezed citrus fruits, it was found that the average percentage of polyembryonic seed formation in each squeezed citrus fruit was $47.92 \%$. As for the growth of citrus seedlings from polyembryonic seeds at 4 weeks of age, the average plant height was $3.075 \mathrm{~cm}$, seed diameter $0.111 \mathrm{~cm}$, number of leaves 2, leaf area $2.21 \mathrm{~cm} 2$, seed dry weight $0.34 \mathrm{~g}$, and a hypothetical vigor of 7.76. Orange seedlings grown from embryozygotes generally have a different appearance from their parents because of the genes that come from two parents. However, the seedlings grown from the Nusaell embryo have the same appearance as the female parent due to somatic cell differentiation.
\end{abstract}

Keywords: embryo, hypothetical vigor, oranges, seed

PENDAHULUAN

Biji merupakan alat perbanyakan

generatif yang proses terbentuknya melalui 2 cara yaitu dari peleburan sperma dengan ovum (amfimiksis) dan

tidak melalui peleburan sperma dengan 
ovum (apomiksis). Amfimiksis dan apomiksis dapat terjadi secara bersamasama sehingga terbentuk satu atau lebih embrio dalam satu ovum. Proses ini disebut poliembrioni seperti yang terjadi pada biji nangka, jeruk dan mangga (Hakim \& Fauzi, 2008). Andrini et al., (2013) menyebutkan bahwa penyebab terjadinya poliembrioni karena pemecahan zigot, perkembangan satu atau lebih sinergid, adanya lebih dari satu kantung embrio per nukleus, dan variasi bentuk opogami dan adventif embrio. Poliembrioni memiliki keistimewaan pada beberapa tanaman seperti mangga, jeruk, manggis, dan duku (Subantoro \& Prabowo, 2012).

Poliembrio pada biji jeruk berasal dari jaringan integument dan nusellus. Jaringan nusellus pada biji jeruk dapat digambarkan seperti kumpulan jaringan juvenile yang memiliki kemampuan regenerasi yang tinggi. Jeruk (Citrus sp) merupakan salah satu genus dari famili Rutaceae yang mempunyai nilai ekonomi paling tinggi. Keragaman genetik jeruk sangat tinggi, yang ditunjukkan oleh tingginya unit taksonomi (spesies dan hibrida) (Yasin et al., 2017).

Embrio nuselar dapat berkembang sampai dengan tingkat awal kotiledon, namun embrio nuselar membutuhkan endosperm untuk berkembang lebih lanjut sehingga polinasi dan fertilisasi tetap dibutuhkan. Jumlah benih per buah dan benih utuh berkorelasi secara signifikan dengan jumlah embrio per benih. Buah dengan banyak benih mempunyai embrio lebih kecil daripada buah dengan sedikit benih yang menghasilkan beberapa embrio yang besar. Ukuran embrio dipengaruhi oleh asal usul embrio, dari benih monoembrioni atau benih poliembrioni. Embrio yang berkembang pada benih monoembrionik lebih besar daripada yang berkembang pada benih poliembrioni. (Andrade-Rodriguez et al. 2004).

Berdasarkan pemaparan di atas diperlukan pengujian terhadap biji jeruk yaitu untuk mengkaji berapa banyak biji poliembrioni dalam suatu buah jeruk dan bagaimana pertumbuhannya. Penelitian bertujuan untuk mengkaji pembentukan benih poliembrioni pada buah jeruk peras dan mempelajari pertumbuhan bibit dari benih poliembrioni

\section{BAHAN DAN METODE}

Penelitian dilaksanakan di Laboratorium Teknologi Benih dan Rumah Kaca, Fakultas Pertanian, Universitas Gadjah Mada, Yogyakarta pada bulan April sampai Mei 2017.

Bahan-bahan yang digunakan yaitu buah jeruk peras dan media tanam berupa pasir. Alat-alat yang digunakan yaitu kapas, kertas saring, cawan petri, 
hand sprayer, pisau, bak perkecambahan plastic, penggaris sebagai alat ukut, jangka sorong, oven Memmert, timbangan digital, alat tulis, dan kamera.

Penelitian dilaksanakan dengan cara memilih buah jeruk yang telah masak dan segar kemudian dipisahkan biji dari buahnya dan dicuci bersih. Bersamaan dengan pembersihan biji jeruk, disiapkan bak perkecambahan yang dialasi dengan kapas dan dibasahi air sampai lembap. Biji jeruk disusun di atas kapas dan dibiarkan sampai mengalami imbibisi selama beberapa hari. Benih yang memiliki jumlah embrio 2, 4, 6, dan 8 dipisahkan untuk perlakuan embrio utuh dan poliembrio. Pada tempat lain yaitu di rumah kaca disiapkan bak perkecambahan biji untuk dengan media tanam pasir yang dilembapkan menggunakan air. Benih yang segar dan sehat dipilih sesuai perlakuan berjumlah 15 atau 25 pada masing-masing unit percobaan. Masingmasing perlakuan diulang sebanyak 4 kali. Benih disusun pada bak perkecambahan dan media tanam dikontrol agar dalam keadaan lembap agar bibit tumbuh dengan baik yaitu selama 3 sampai 4 minggu.

Parameter yang diamati yaitu persentase perkecambahan benih poliembrioni dengan cara menghitung jumlah benih yang berkecambah terhadap jumlah benih yang dikecambahkan. Pertumbuhan bibit yang dilakukan pada umur 3 sampai 4 minggu antara lain: tinggi bibit $(\mathrm{cm})$, luas dan $\left(\mathrm{cm}^{2}\right)$, jumlah daun (helai), berat kering tanaman (g), diameter batang $(\mathrm{cm})$, dan vigor hipotetik. Vigor hipotetik dihitung menggunakan persamaan I.

$$
\mathrm{VH}=\frac{\log A+\log B+\log C+\log D+\log E}{\log T}
$$

Keterangan: VH (vigor hipotetik); A (jumlah daun); B (luas daun); C (tinggi bibit); D (berat kering tanaman); E (diameter batang); $\mathrm{T}$ (umur bibit dalam minggu)

\section{HASIL DAN PEMBAHASAN}

Tabel 1 menunjukkan bahwa rerata persentase bibit poliembrio pada buah jeruk cukup tinggi yaitu 47,92 \%. Pembentukan biji poliembrioni pada tanaman jeruk ditunjukkan dengan banyaknya embrio nuselar non zigotik yang berinisiasi secara langsung dari sel induk dimana sel-sel nuselar tersebut mengelilingi kantung embrio yang berisi embrio zigotik yang sedang berkembang. Selama perkembangan kantung embrio, sel-sel embrionik nuselar mendapatkan jalan masuk ke endosperm dan berkembang menjadi embrio di sepanjang embrio zigotik. Embrioembrio nuselar tersebut terus berkembang dan menghasilkan beberapa semaian dengan genotipe yang sama dengan tetua betina. 
Tabel 1. Persentase bibit poliembrio pada setiap buah jeruk

\begin{tabular}{|c|c|c|}
\hline Ulangan & Buah Ke & Persentase Poliembrio (\%) \\
\hline \multirow{2}{*}{$\mathrm{U} 1$} & buah 1 & 57,14 \\
\hline & buah 2 & 100 \\
\hline \multirow{2}{*}{$\mathrm{U} 2$} & buah 1 & 12,5 \\
\hline & buah 2 & 42,85 \\
\hline \multirow{3}{*}{ U3 } & buah 1 & 0 \\
\hline & buah 2 & 33,33 \\
\hline & buah 3 & 75 \\
\hline $\mathrm{U} 4$ & buah 1 & 62,5 \\
\hline \multicolumn{2}{|c|}{ Rerata } & 47,92 \\
\hline
\end{tabular}

Sifat poliembrioni pada jeruk terjadi karena adanya embrio nuselar. Embrio nuselar berkembang dari jaringan maternal benih yang berkembang bersamaan dengan embrio zigotik sehingga dalam satu benih bisa muncul lebih dari satu bibit (Frost \& Soost, 1968). Embrio zigotik merupakan embrio yang terbentuk dari fusi antara gamet jantan dan gamet betina sedangkan embrio nuselar terbentuk dari jaringan nuselar tanpa melalui fertilisasi (Salisbury \& Ross, 1992). Embrio nuselar merupakan bentuk adventif dari reproduksi yaitu sel somatik dari jaringan nuselus diinisiasi untuk memasuki lintasan perkembangan embrionik. Embrio nuselar berkembang dari sel inisial nuselus yang berasal dari jaringan nuselus yang mengelilingi kantong embrio. Tidak terdapat kontribusi gamet jantan dalam pembentukan embrio nuselar. Dengan demikian, semaian asal embrio nuselar bersifat identik dengan induknya kecuali terdapat variasi somatik (Kepiro \& Roose, 2007).

Di antara bibit yang tumbuh pada biji poliembrioni terdapat embrio yang tidak berkembang atau kerdil, diduga embrio ini merupakan embrio zigotik yang merupakan embrio hasil peleburan gamet jantan dengan gamet betina. Pada umumnya bibit yang berasal dari embrio nuclear memiliki vigor yang lebih baik, sehingga mampu tumbuh lebih baik. Perbedaan embrio zigotik dengan embrio nuselar dapat diindikasikan dari penampakan morfologinya. Bibit yang tumbuh dari embriozigotik umumnya memiliki tampilan yang berbeda dari induknya, hal ini disebabkan oleh gen dari bibit ini berasal dari dua tetua yaitu jantan dan betina. Sedangkan bibit yang tumbuh dari embrio nuselar memiliki tampilan morfologi yang identik dengan induk betinanya, karena merupakan hasil deferensiasi dari sel somatik induk betina, dan biasanya memiliki 
pertumbuhan yang relatif lebih cepat dan seragam. Perbedaan embrio zigotik dan embrio nuclear tersaji pada Gambar 1.

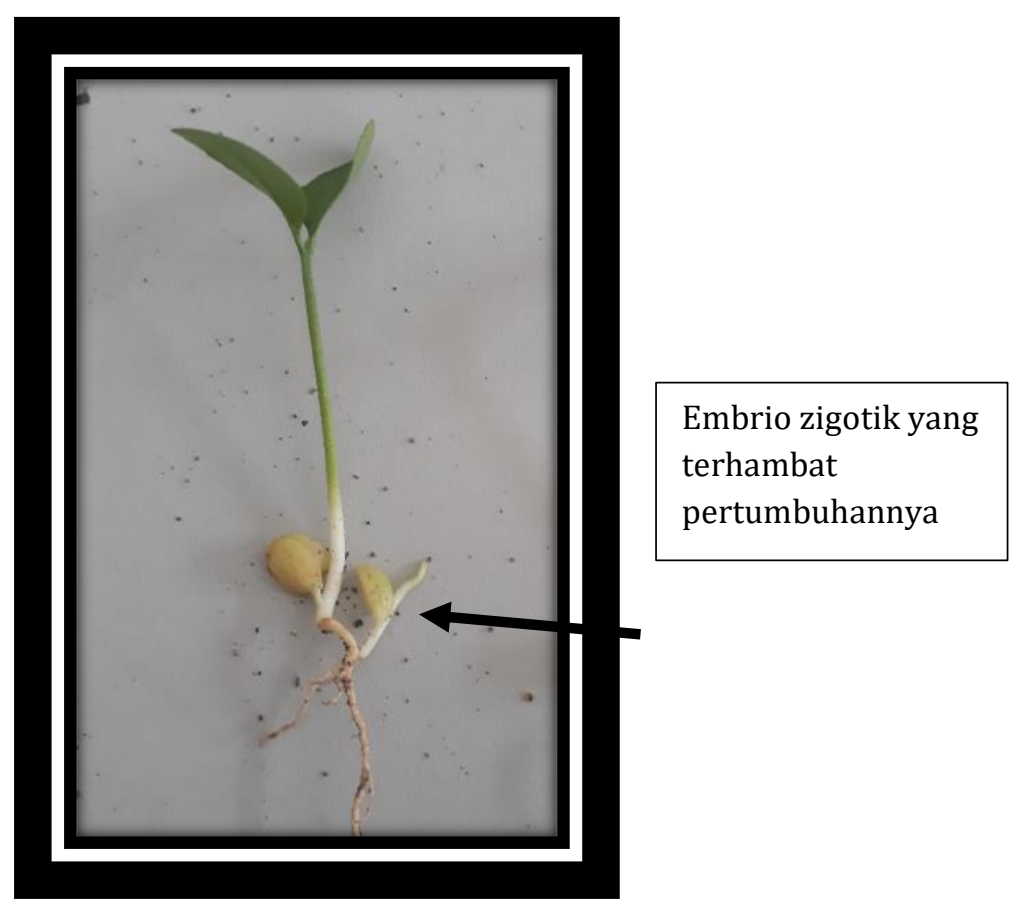

Gambar 1. Perbedaan embrio zigotik dengan embrio nuclear

Tabel 2 menunjukkan bahwa jumlah benih per buah dan benih utuh berkorelasi secara signifikan dengan jumlah embrio per benih. Buah dengan banyak benih mempunyai embrio lebih kecil daripada buah dengan sedikit benih yang menghasilkan beberapa embrio yang besar. Ukuran embrio dipengaruhi oleh asal usul embrio, dari benih monoembrioni atau benih poliembrioni. Embrio yang berkembang pada benih monoembrionik lebih besar daripada yang berkembang pada benih poliembrioni. (Andrade-Rodriguez et al., 2004).
Pertumbuhan bibit monoembrio memiliki vigor hipotetik yang lebih baik dibandingkan dengan pertumbuhan bibit poliembrio. Hal ini disebabkan oleh beberapa factor antara lain banyaknya cadangan makanan yang terdapat di dalam daun dikotil, semakin sedikit embrio yang ada dalam satu biji maka akan semakin sedikit pembagian cadangan makanan yang akan digunakan untuk pertumbuhan, sehingga biji yang memiliki embrio 1 menunjukkan pertumbuhan yang lebih baik dibandingkan dengan biji yang memiliki embrio lebih dari 1. 
Tabel 2. Hasil pengamatan dan perhitungaan vigor hipotetik bibit jeruk poliembrioni

\begin{tabular}{|c|c|c|c|c|c|c|c|c|}
\hline $\begin{array}{l}\text { Jumlah } \\
\text { embrio }\end{array}$ & Ulangan & Buah & $\begin{array}{l}\text { Tinggi bibit } \\
\text { (cm) }\end{array}$ & $\begin{array}{l}\text { Diameter } \\
\text { (cm) }\end{array}$ & $\begin{array}{c}\text { Jumlah } \\
\text { daun } \\
\text { (helai) }\end{array}$ & $\begin{array}{l}\text { Luas } \\
\text { daun } \\
\left(\mathrm{cm}^{2}\right)\end{array}$ & $\begin{array}{l}\text { Berat } \\
\text { kering } \\
(\mathrm{g})\end{array}$ & $\begin{array}{c}\text { Vigor } \\
\text { hipotetik }\end{array}$ \\
\hline \multirow{8}{*}{1} & 1 & 1 & 4,03 & 0,12 & 2,33 & 3,46 & 0,74 & 9,09 \\
\hline & & 2 & 0 & 0 & 0 & 0 & 0 & 0 \\
\hline & 2 & 1 & 3,31 & 0,12 & 2,00 & 2,85 & 0,42 & 8,27 \\
\hline & & 2 & 3,13 & 0,11 & 2,00 & 2,40 & 0,31 & 7,84 \\
\hline & 3 & 1 & 2,42 & 0,11 & 2,00 & 2,35 & 0,24 & 7,46 \\
\hline & & 2 & 3,20 & 0,11 & 2,00 & 3,13 & 0,48 & 8,37 \\
\hline & 4 & 1 & 3,20 & 0,11 & 2,00 & 3,14 & 0,32 & 8,06 \\
\hline & & 2 & 3,60 & 0,11 & 2,00 & 3,14 & 0,59 & 8,59 \\
\hline \multirow{8}{*}{2} & 1 & 1 & 3,10 & 0,12 & 2,00 & 2,20 & 0,39 & 7,95 \\
\hline & & 2 & 3,20 & 0,11 & 2,00 & 2,25 & 0,35 & 7,88 \\
\hline & 2 & 1 & 2,80 & 0,11 & 2,00 & 1,90 & 0,32 & 7,60 \\
\hline & & 2 & 3,27 & 0,11 & 2,00 & 2,50 & 0,36 & 8,01 \\
\hline & 3 & 1 & 0 & 0 & 0 & 0 & 0 & 0 \\
\hline & & 2 & 3,10 & 0,11 & 2,00 & 2,55 & 0,32 & 7,88 \\
\hline & 4 & 1 & 3,00 & 0,11 & 2,00 & 2,70 & 0,34 & 7,93 \\
\hline & & 2 & 3,36 & 0,11 & 2,00 & 2,50 & 0,38 & 8,07 \\
\hline \multirow{8}{*}{3} & 1 & 1 & 3,10 & 0,11 & 2,00 & 1,88 & 0,38 & 7,78 \\
\hline & & 2 & 0 & 0 & 0 & 0 & 0 & 0 \\
\hline & 2 & 1 & 0 & 0 & 0 & 0 & 0 & 0 \\
\hline & & 2 & 0 & 0 & 0 & 0 & 0 & 0 \\
\hline & 3 & 1 & 0 & 0 & 0 & 0 & 0 & 0 \\
\hline & & 2 & 3,10 & 0,11 & 2,00 & 2,00 & 0,28 & 7,61 \\
\hline & 4 & 1 & 0 & 0 & 0 & 0 & 0 & 0 \\
\hline & & 2 & 0 & 0 & 0 & 0 & 0 & 0 \\
\hline \multirow{8}{*}{4} & 1 & 1 & 0 & 0 & 0 & 0 & 0 & 0 \\
\hline & & 2 & 0 & 0 & 0 & 0 & 0 & 0 \\
\hline & 2 & 1 & 0 & 0 & 0 & 0 & 0 & 0 \\
\hline & & 2 & 0 & 0 & 0 & 0 & 0 & 0 \\
\hline & 3 & 1 & 0 & 0 & 0 & 0 & 0 & 0 \\
\hline & & 2 & 0 & 0 & 0 & 0 & 0 & 0 \\
\hline & 4 & 1 & 2,80 & 0,11 & 2,00 & 1,60 & 0,22 & 7,20 \\
\hline & & 2 & 0 & 0 & 0 & 0 & 0 & 0 \\
\hline
\end{tabular}

\section{SIMPULAN}

Berdasarkan pengamatan terhadap beberapa buah jeruk peras didapat bahwa rerata persentase pembentukan benih poliembrioni pada setiap buah jeruk peras yaitu 47,92\%. Adapun pertumbuhan bibit jeruk asal benih poliembrioni saat berumur 4 minggu yaitu tinggi tanaman rata-rata sebesar $3,075 \mathrm{~cm}$, diameter biji $0,111 \mathrm{~cm}$, jumlah daun 2 helai, luas daun $2,21 \mathrm{~cm}^{2}$, berat kering bibit 0,34 g, dan vigor hipotetis sebesar 7,76. Bibit jeruk yang tumbuh dari embriozigotik umumnya memiliki tampilan yang berbeda dari induknya karena gen yang berasal dari dua tetua. Namun bibit yang tumbuh dari embrio nuselar memiliki tampilan yang sama dengan induk betina akibat diferensiasi sel somatik. 


\section{DAFTAR PUSTAKA}

Andrade-Rodríguez, M., Villegas-Monter, A., Carrillo-Castañeda, G., \& GarcíaVelázquez, A. (2004). Polyembryony and identification of Volkamerian lemon zygotic and nucellar seedlings using RAPD. Pesq. agropec. bras., Brasília. 39(6), 551-559.

Andrini, A., Suharsi, T. K., \& Surahman, M. (2013). Studi poliembrioni dan penentuan tingkat kemasakan fisiologis benih Japansche Citroen berdasarkan warna kulit buah. Jurnal Hortikultura 23(3), 195-202

Frost, H. B., \& Soost, R. K. (1968). Seed reproduction: Development of Gametes and Embryo. Di dalam: Reuther W, Batchelor LD, Webber $\mathrm{HJ}$, editor. The Citrus Industry. Volume II. Anatomy, Physiology, Genetics and Reproduction. California (US): 290-324.

Hakim, L., \& Fauzi, M. A. (2008). Pengaruh Ukuran Kotiledon
TerhadapPertumbuhan Semai Ulin (Eusyderoxylon zwageri T. Et B). Jurnal Pemuliaan Tanaman Hutan 2 (1), 2-5.

Kepiro, J. L, \& Roose, M. L. (2007). 'Nucellar Embryony', In Khan, IA (ed.). Citrus Genetics, Breeding and Biotechnology. London (GB), Biddlles Ltd, Kings Lynn.

Salisbury, P. B., \& Ross, C. W. (1992). Plant Physiology. California (US): Wadsworth Pub.Com.belmont. hlm 682.

Subantoro, R, \& Prabowo, R. (2012). Benih poliembrio pada tanaman kokosan dan jeruk. Mediagro 8(1), 86-97.

Yasin, M., Saptadi, D., Kendarini, N., \& Agisimanto, D. (2017). Keragaman genetic hasil aplikasi kolkhisisn pada tanaman jeruk siam cv. Pontianak (Citrus nobilis) secara morfologi dan molekuler. Jurnal produksi tanaman 5(11), 18351844. 